\title{
Political causes and factors influencing protests of miners in Russia (1992-1999)
}

\author{
Tatiana S. Kust ${ }^{1, a}$, Igor S. Solovenko ${ }^{1}$, Petr P. Rumyantsev ${ }^{2}$ \\ ${ }^{1}$ Tomsk Polytechnic University, 634050 Lenin Avenue, 30, Tomsk, Russia \\ ${ }^{2}$ Tomsk State University, 634050 Lenin Avenue, 36, Tomsk, Russia
}

\begin{abstract}
The paper provides identification of political causes and factors of miner protest campaigns in the post-soviet Russia. The following research methods have been applied: contrastive-comparative analysis of literature on historic, sociological, political science, philosophic and economic issues; the method of statistical processing of the information; historical-typological analysis and generalization of documents in force and archival materials; the method of historical simulation. The authors gradually identified the most relevant political causes and factors affecting the development of miner protest campaigns in 1992-1999. Their interdependence on economic and socio-cultural aspects of phenomenon under consideration is also revealed. A comparative analysis with the "perestroika" period (1989-1991) was carried out. The authors made a conclusion that socio-political and socio-economic processes in coal mining regions were highly dependent on the policy of the federal center. The «experimental» nature of reforms in coal mining industry was not supported by additional political powers of leaders in coal mining territories, as the result, the policy was far behind economy and the social sphere of miners. Regional and local authorities were in the conditions of natural (market) selection; therefore, they spent most of their time keeping their political positions by any means, without any attempts to solve the problems in miner towns and settlements.
\end{abstract}

\section{Introduction}

The reasons, due to which miners and their families had to face the most social and economic problems in the 1990-s, were political mistakes and oversights at all governmental levels. Political authorities of the country relied too much on outside assistance and were not able to take the advantages of liberal reforms in some European countries. They also under-evaluated its own historical experience in conducting market transformations. The situation was worsened by urgent challenges in the country and within the international scope (confrontation between the president and the Parliament, radical trends in the state structure, the situation in the Balkans). In the early 1990-s, a period of serious political conflicts began in the Russian society. Both Russian and foreign scientists studied political causes and factors of Russian miners' protest campaigns (1992-1999). All historians emphasized high proneness to conflicts in the post-soviet society because the reality contradicted expectations. A new system of sociopolitical relations was especially complicated for the employees of coal mining industry, supporting Yeltsin on his way to reforms for a very long time. The papers of Russian and foreign authors differ mainly in their attitude to political reasons of evolving miners' protest

\footnotetext{
a Corresponding author: tatjana.kust@yandex.ru
}

campaigns. Miners made an emphasis on personality of the president B. Yeltsin who was not able to ensure adequate living standards for them. This fact accentuated inhomogeneity and internal contradictions in miner community.

\section{Materials and methods}

In the paper, the following research methods have been applied: contrastive-comparative analysis of literature on historic, sociological, political science, philosophic and economic issues; method of statistical treatment of information; historical-typological analysis and generalization of documents in force and archival materials; method of historian simulation. The authors collected memories of more than 20 people who took part in the events under consideration in order to supplement investigation with little-studied details.

\section{Results and discussion}

Some phases, distinguished by the impact of certain causes and factors, are identified in the development of miners' protest campaigns. 
In view of political relations between miners and authorities, the first phase (1992-1997) is the most contradictory one. It caused the long-continual character of miners' dissatisfaction with the policy of the Kremlin. Protest campaigns were developing smoothly in the period under consideration mainly due to hopes of miners that the government could carry out political and economic reforms the strikers had insisted on in 19891991.

As liberal transformations were initiated, employees in the coal mining regions strived for keeping their important position and function in social and political processes they had had since 1989. The breakdown of the USSR and establishment of a new Russian statehood changed the political status of the miner community; it became a key champion of reformatory Yeltsin's ideas among common workers. No wonder, miners aspired to better positions in a newly formed system of social and political relations. But their claims on both a special position and an important role in political processes within the country were unsubstantiated.

In their turn, miners did not want to accept such political, moreover, social and economic situation. In the early 1990 -s they thought they could influence the policy of their region and the country on the whole. The latest experience of the soviet system collapse made them think they would have been successful if the government had been placed under pressure. Moreover, the authority of miners in coal-mining regions and in the country on the whole was quite significant at that time. The profession of miners always distinguished them for their high courage and fortitude against the background of other workers. This fact provoked independent struggle and brought them together with anti-governmental social and political forces and some politicians. They needed their own president, who could reserve miners' status of "working elite". Finally, miners changed their attitude to B. Yeltsin, having become not his supporters, but active opponents.

The inertia of high political engagement in the staff of coal-mining enterprises, glorification of their strike movement etc. provoked new mass protest actions; undermined discipline, and had a negative impact on production management. The struggle of workers in coal mining industry was similar to "perestroika" protests.

Therefore, miners' efforts to spread their influence on social and political processes in the country were often destructive because of illegal protest actions; in fact, they undermined stability in coal-mining regions.

The positive evolution character of protest actions was caused by opposition of miners' trade unions - the Independent Trade Union of Russian Miners and Rosugleprof. They differed in their origin, political guidelines, goals and objectives, as a consequence, they were in opposition to each other. The Independent Trade Union of Russian Miners supported the president, while industry-specific managerial bodies relied on Rosugleprof, which was close to the Communist party [2].

Since the first year of market transformations, trade union organizations had been fighting severely for dominance among miners, first of all, in mass media. In conditions of economic decline and worsening of social situation in miners' towns and settlements, mass protest actions organized by Rosugleprof demoralized the activity of the Independent Trade Union of Russian Miners. In this case, the latter had to change its tactics of battling for miners' interests. Supporting democratic and market reforms of the president, the Independent Trade Union of Russian Miners often criticized particular actions of the Government of the Russian Federation and called upon its supporters for protest actions. Fighting for the leadership, these organizations took part in demonstrative protest actions; some of them were radical ones.

In the end, the miner community became separated and uncoordinated, as the result, the solidarity of the strategy and tactics of struggle weakened. Miners got more dissatisfied because of general political instability in the country and in coal mining regions. The reason for this instability consisted in opposition of legislative and executive branches of government. As a rule, legislative bodies of all levels represented the interests of people dissenting with the methods of "shock therapy". Political conflict of the president and the Supreme Soviet of the RSFSR was the most critical. In these conditions, workers of coal-mining industry were divided into supporters and opponents of these government institutions. In 1992 working committees and the Independent Trade Union of Russian Miners actively involved miners into actions to support economic reforms of the president, opposed to "the conservative" parliament.

Meanwhile, the sympathy of miners with B. Yeltsin was not as mass as in 1989-1991. On the contrary, such campaigns were not apprehended both by other groups of workers and by miners in coal mining regions. The key cause was in worsening living standards of population conditioned by liberal reforms. Attempts of the legislative power to correct the course of "shock therapy" led to bigger chaos and difficult political crisis in autumn 1993, which was surmounted by adoption of a new Constitution and elections into the State Duma.

However, local legislative authorities, being beyond the control of the president of the Russian Federation, supported the struggle of miners for their labor rights and social guarantees in regions. The attempts of the executive governmental branch to "get hold of" "obedient" deputies were unsuccessful.

"Dual power", being not so decisive though, was also typical for the country after adoption of the new Constitution of the Russian Federation. It manifested itself in constant competing accusations of the president and deputies of opposition in the State Duma, in such issues as acceptance of unreal budgets, etc. Severe struggle of legislative power against the executive governmental branch caused political chaos in the country and in coal-mining regions.

Radical reforms gave birth to radical opposition. Miners' protest moods were seriously affected by "left" parties and movements, since the mid 1990-s. Dissemination of left-patriotic attitudes in the milieu of miners was not as successful as in other groups of workers, but they became unavoidable due to political 
weakness of the Kremlin, unfair character of reforms, growing corruption etc. The authorities of the government and the president of the Russian Federation were steadily going down.

A number of failures in inward and international affairs raised an issue of the Russian state substantiate possibility as a comprehensive whole. After the Supreme Soviet of the RSFSR had been dissolved, B. Yeltsin could not shift the blame of mistakes and errors of judgments of "shock therapy" on other political institutions. As a consequence, coal-mining workers entered into alliance with left-patriotic forces with the communist Party of the Russian Federation as a chief player. This alliance became a political top-priority of miners at that time. Social-economic and political mottos of socialism-oriented organizations and those of miners gradually coincided. They received evidence that democracy would not make people rich automatically.

The influence of left organizations on miners increased after the communist party had won the elections into the State Duma in 1995. The communist party gained in popularity among the common people because of its uncompromising attitude to the methods of market transformations. The communists and their representatives organized and took part in mass and radical protest actions of miners. Their views were taken into account in the claims of miners arranging protests. The presidential elections in 1996 made it evident that B. Yeltsin had much fewer supporters than one thought in the Kremlin [7].

The second phase (January-July 1998) was characterized by the culminating crisis phenomena in social and political conditions of the country and coal mining regions. The surge of miners' displease was caused mainly by the weak line of command, to say more, there was no single political position of the executive power at all levels. The Kremlin was not able to create an efficient mechanism to coordinate actions with authorities of the Russian Federation constituents. Measures taken to solve social and industrial conflicts were uncoordinated, even contradictory.

The Kremlin did not have a clear view of crises phenomena in the economy of the country, especially in depressive regions. The heads of Russian Federation constituents were blamed for many social and economic difficulties, while the real assistance from the center came at extraordinary moments. It undermined miners' faith in laws and order and made the heads of Russian Federation constituents turn into hidden opposition or open dissent to the Kremlin. The shift in the electoral system towards electing heads of subjects of the federation worsened the interrelations of the center with heads of coal-mining regions. A strong regional antipresident coalition was formed.

The spring of 1998 was distinguished by the governmental crisis, which complicated the solution of urgent issues in coal-mining regions. The resignation of Chernomyrdin increased the irresponsibility of state authorities in terms of the relations with workers of coalmining industry. The workers were disoriented in a proper address of their claims. Representatives of the government occasionally visited an explosive part of the country, but did not make any attempts to find an integrated solution of miners' problems.

In the government of the Russian Federation there was nobody who could negotiate with miners because various problems of coal-mining were in the competence of different departments of Ministry of Fuel and Energy. The Cabinet of Ministers often violated the agreements made earlier and digressed from its own policy of social compliance. On the eve of "rail wars" in May the president and the government gave promises to provide the industry with supplementary finances. The character of those promises was revealed from the results of AllRussian Congress of Coal-Mining Industry Workers in April 1998. Despite this fact, ministers accused miners in making unreal demands [3] and were hardly interested in having a dialog with them.

A new head of the Cabinet of Ministers S. Kirienko did not respond properly to the claims of miners, making the miners" ideas of a "good" president and a "bad" government groundless. The illusions of the most employees that B. Yeltsin had a political potential were dispelled completely. Contradictions between the biggest part of the miners' community and governmental bodies obtained a character of naked hostility and threatened with social fallout in May 1998.

In general, the Federal Government did not react properly to social and economic problems in towns and settlements of miners because they were unimportant to them. This underestimation worsened the relations with workers of coal mining industry and led to open and uncompromising struggle in May - July 1998.

Confrontation between executive and legislative governmental branches was in the center of social and political instability during the first and second phases. It was not as apparent and uncompromising as in the early 1990-s, but sometimes proneness to conflicts reached its culmination. The opposition party of the State Duma was supported by the legislative authorities in coal-mining regions, so its deputies have more courage to confront the president. Opposition parties gained their popularity due to sharp criticism of social and economic policy of the Kremlin in the Lower House of the Parliament.

The confrontation between the president and the Sate Duma got sharper because of the constitution of the new Cabinet of Ministers in March 1998. This confrontation led to a long governmental crisis. An attempt of impeachment of the president, initiated by the group of the Communist party in the State Duma was a show action.

The fight of two branches of government did not facilitate taking well-timed measures to overcome crisis in the economy on the whole and in coal mining industry, in particular. Bankruptcy of populist governmental mottos in May - July 1998 caused mass, radical, illegal but legitimate protest actions of workers.

In general, ongoing confrontation of two governmental branches did not support solutions, which could improve the living standards of workers.

Evolving miners' struggle was conditioned by a serious lag of the legal sphere from the principles of political and social-economic relations. The mechanism was not efficient even for protection of labor rights of 
workers when it was necessary to find the guilty for arrears in payment. There were three reasons: no regulatory structure to investigate economic crimes, immature of legal culture and inefficient activities of law enforcement agencies.

In the period under consideration, there were no legal documents or methods to investigate business law offences, which could meet the new market reality [4]. Corrupt directors of companies, dishonest agents and other partners of workers could decline the responsibility.

Insufficient legal culture of citizens manifested itself in inadequate information how their economic rights and interests could be upheld. Although this information could be found in legislative acts, the rights of workers and employees of government-financed companies were not guarantied or broken. However, only some of them applied to law-enforcement agencies, a fortiori, in coalmining regions. On the one hand, law-enforcement agencies were distrusted, people did not want to have long and annoying lawsuits. On the other hand, it was assumed that radical protest campaigns could enable the process of drawing the salaries that were held over.

Insufficient immediacy, efficiency and independency of law-enforcement agencies, as well as growing corruption among the employees of these agencies became evident for everybody.

Up to "rail wars" in May 1998 no sufficient measures were taken by employees of public prosecutor's office to ensure discipline; administrative cases were not brought before the court, everybody knew about months-long arrears of payment though.

As the result, the second period was distinguished by widely occurring radical protest actions. Constant disability of the legal system to solve labor conflicts in a civilized way was the reason for these actions.

Inefficient activities of regional and local authorities, especially in solution of social and economic problems were key causes why miners' protests got more radical. The weakness of governmental bodies in the coal mining regions in 1990-s is emphasized by many factors. They are: essential decline in production, high level of unemployment, purposeless use of budgetary funds, a low level of charged taxes, growth of corruption, increasing number of crimes, uncertain and contradictory actions of law enforcement bodies etc. Social and political stability was also threatened by financially violating actions of authorities in coal mining regions, first of all, in the field of budgetary policy.

The authorities of coal-mining regions supporting miners' campaigns often tried to readdress the protests to central governmental bodies and directors [6]. It made knotty problems in relations of the Russian Federation constituents with the Kremlin even more complicated, and restricted possibilities of authorities to solve largescale labor conflicts.

The weakness of authorities in coal mining regions was conditioned both by insufficient political and economic support on the part of the Kremlin and professional immature of many politicians being in power at that time to implement their own slogans, declared in the late 1980-s and in the early 1990-s.
Low economic efficiency of reforms, insufficient financing and lack of command line weakened the activities of municipal governmental bodies over the 1990-s. The heads of miner towns and settlements, especially small and mono-profiled ones were in very difficult conditions.

Local authorities made the following irresponsible mistakes: population was not kept informed about new places of work, impracticable promises were declared, they hoped so much to get assistance from regional and federal governments, they did not respond to mass violations of labor laws etc. Local administration was uncertain, inconsistent in contacts with participants of the protests, as the result, radical viewpoints of miners got stronger.

Therefore, the second phase was distinguished by the increase of political causes and factors influencing activation of miners' protest campaigns. It is also important they had a complex and interrelated nature. Stagnating and liberal executive power (western experts also noted it [8]) endangered economic order and political integrity of the country.

The third phase (August 1998 - 1999) is distinguished by falling political stringency in coal mining regions. After serious shocks since August 1998 they and the whole country witnessed that the social and political situation was gradually getting more stable. On the other hand, positive processes in inward policy balanced on the edge of social collapse. Top-priority issues of miners were as urgent as before.

Over the third phase, which was rather short, the Cabinet of Ministers was changed three times. Governmental crises were unavoidable elements of political situation in the country. The inward policy of B. Yeltsin could not be predicted and influence the solution of social and economic problems in coal mining regions. This government reshuffle made left-patriotic and other political forces insistently criticize the Kremlin and furthered the growth of opposition viewpoints in the society.

The change of the government had the most negative impact on living standards in miner towns and settlements when the country suffered from the outcomes of international financial and economic crisis. After default on August, 17, in 1998 and before the new government headed by E. Primakov had been formed nobody dealt with the problems of coal mining industry. The complex situation in the economy and social sphere of the country including back pay of salaries and pensions got more complicated because there was no Cabinet of Ministers in the country.

The change of the government was accompanied by failures of inward policy of the president, promoted growth of opposition viewpoints both in various strata of society and among heads of the Russian Federation constituents. In autumn 1998, 79 heads of regions came out against B. Yeltsin (according to the results of voting in the Soviet of Federation) [1]. So, the stable antipresident regional coalition was formed.

The surge of opposition viewpoints in Russian society in spring - summer, 1998, was an additional factor of activating political activities of opposition 
parliament and non-parliament parties and movements. Their main goal was to increase influence on labor movement, including miners. Forms and methods to raise their impact were different, but all of them criticize their opponents in order to attract miners' attention.

Opposition parliament parties (the Communists, Liberal Democratic Party of Russia etc.) made attempts to extend the sphere of their influence by attracting votes of population in coal mining regions while struggling for seats in the State Duma. Addressing the electorate they gave protest actions of miners and their radical slogans moral support and used populist ideas. Therefore, opposition parliament parties undermined prestige of the president, their trust to his social and economic policy and incited the electorate of miner towns and settlements to continue anti-president struggle.

The Communist party was the most oppositionoriented one, which set the course for mass protest campaigns all over the country in September 1998, collected money to support miners' protests in Moscow, arranged the preparation of the general political strike [5] etc.

1998 - 1999 was a period when a number of new radical social and political organizations acting in the name of workers appeared. Their actions were directed at consolidation of workers of various professions to uphold their class interests. It was an additional impulse to increase social and political tensions in coal-mining settlements and towns.

In general, activation of opposition parliament and non-parliament parties, as well as social and political organizations was a key factor of ongoing protest potential of miners. Their wide range gave miners an opportunity to find an opposition group they trusted.

To sum up, political dissatisfaction of miners was not so strong during the third phase and turned latent for some objective and subjective reasons.

\section{Conclusion}

The analysis of political causes and factors of protest campaigns of miners let the authors make a conclusion that socio-political and socio-economic processes in coal mining regions were highly dependent on the policy of the federal center. The «experimental» nature of reforms in coal mining industry was not supported by additional political powers of leaders in coal mining territories; as the result, the policy was far behind the economy and social sphere of miners. Regional and local authorities were in the conditions of market selection. Consequently, they spent most of their time keeping their political positions by any means, without any attempts to solve the problems of miner towns and settlements.

\section{Acknowledgment}

The programme was realized and subsided within the framework of the Programme for enhancing Tomsk Polytechnic University's competitiveness. The results presented in this paper were obtained with the support of the Russian Fund.

\section{References}

1. S. Harte, J. Grävingholt, H. Pleines, H-H. Schröder, Geschäfte mit der Macht, 216, 29 (2003)

2. I.S. Solovenko, T.S. Kust, Procedia - Social and Behavioral Sciences, 166, 660-665 (2015)

3. I. Khmylko, Zapolyarye (Vorkuta) July, 11 (1998)

4. National Archive of Komi Republic, Fond 1307, Inventory 1, Case 1880, List 87

5. H. Pleines, Arbeitspapiere und Materialien, 80, 28, 29 (2006)

6. Striking miners block Russian railroads. Lessons of the GM strike; about the Puerto Rican general strike; and striking Russian miners blockade railroads: Detroit Workers Voice [Online]. Available: http://home.flash.net/ comvoice/DWV20.html (August 9, 2011)

7. V.I. Chekalkin, Vlast, 10-11, 22, 23 (1998)

8. National Archive of Komi Republic, Fond 3791, Inventory 1, Case 31, List 37 